\section{Risks and critical issues related to the discovery on the market of unauthorized live alien species on the Italian territory: Chinese crab (Eriocheir sinensis)}

\author{
Federica Maria Sessa, ${ }^{1}$ Luca Cianti, ${ }^{2}$ \\ Nicola Brogelli, ${ }^{1}$ Lara Tinacci, ${ }^{3}$ \\ Alessandra Guidi ${ }^{3}$ \\ ${ }^{1}$ Food Chain Studio associato, Firenze; \\ ${ }^{2}$ Azienda USL Toscana Centro, Firenze; \\ ${ }^{3}$ Dipartimento di Scienze Veterinarie, \\ Università di Pisa, Italy
}

\begin{abstract}
Eriocheir sinensis, Chinese Crab or Chinese Mitten Crab is a catadromous species belonging to the Varunidae family, native to river and estuarine areas of North and South East China and Korea. At European level, E. sinensis is widespread in the main water basins of Central and Northern Europe and, since 2016, it has been included in the list of invasive species important for the European Union and subjected to confinement and eradication measures which include the prohibition of collection, transit and placing on the market of live specimens (Regulation (EC) $\mathrm{N}^{\circ}$ 1143/2014). The Chinese Crab can represent a significant danger for the local ecosystem and for the native biota as well as contributing to the appearance of hydrogeological instability phenomena resulting from the intense excavation and erosion of the riverbanks.
\end{abstract}

The first finding of $5 \mathrm{~kg}$ of live specimens of Eriocheir sinensis was recorded in the official control by the UFS (Functional Simple Unit) veterinary public health and food safety of the ASL Toscana Centro at an ethnic catering establishment. The specimens were subjected to seizure, photographed, identified morphologically, and subjected to euthanasia and destruction in accordance with the European requirements for welfare and management of animal by-products.

From the sanitary point of view, the dangers associated with the consumption of this crab are mainly biological and chemical therefore, risk communication is fundamental, not only at the level of the competent authorities in the sector, but also for the food business operators.

\section{Introduction}

Eriocheir sinensis, is a crab belonging to the Varunidae family commonly known as
Chinese Mitten Crab. The presence of $E$. sinensis in Europe is reported since the early 1900s plausibly due to the accidental introduction of zoea larval stages through ballast waters (Bentley, 2011; Hopkins, 2001). The first survey was recorded in Germany in 1912, in the Aller river near the city of Rethem and in 1914 in the Elbe river (Hymanson et al., 1999). More recently, alternatives routes for the introduction of the species within the European borders has been hypothesized as consequence of its import for food purpose generally related to Asian cuisine specialties (Robbins, et al., 2003).

Indeed, in East and South-East Asia E. sinensis is recognized as one of the most commercially valuable crabs and it is presented on the market in various forms (alive, fresh or frozen) for the preparation of traditional delicacies such as soup or cold cuts (Clark et al., 2009; Hoogenboom et al., 2015). The crab gonads are particularly appreciated and included within the highestclass dishes proposed in China, Japan and Singapore (Clark, 2011).

As regard as Mediterranean Sea area, E. sinensis first appearance was recorded in 1959 near Narbonne, further reports were lost until early 2000s when a specimen was captured in the lagoon of Venice (Mizzan, 2005). Since then, E. sinensis has been periodically sighted within this area until 2014 (Fiorin, et al., 2013; Bettison and Comisso, 2015).

E. sinensis arouse specific attention internationally being listed within the first 100 alien species with the highest invasive potential due to its extreme euryhalinity, as catadromous species, which allows the crab survival in both fresh and marine waters and the high reproductive index and the adults burrowing habit which produces degradation and erosion of water channels and the banks of waterways (Bentley, 2011; DAISIE, 2015; Dittel and Epifanio, 2009).

Under the European legislation the prevention and management of the introduction and spread of invasive alien species is ruled by the Regulation (EC) $\mathrm{N}^{\circ}$ $1143 / 2014$ which specifically prohibits, within the Union, the import, transit, feeding selling and free release in the environment of alive specimens belonging to ascertained alien invasive species listed in periodically updated lists. In this respect, a dedicated Regulation (EU Execution Regulation No. 2016/1141) has been enacted and within the list currently in force $E$. sinensis is included. Therefore, Chinese Mitten Crab is allowed for import only as fresh or frozen product while even the transport of alive specimen is forbidden.

Thus, the present study, following a
Correspondence: Federica Maria Sessa, Food Chain studio associato, via G. Guinizzelli 24, 50133, Firenze (FI), Italy.

Tel: +39 3495456481 .

E-mail: federicamaria.sessa@gmail.com

Key words: Eriocheir sinensis; Chinese Mitten Crab; invasive species; official control; risks and critical issues.

Contributions: The authors contributed equally

Conflicts of interest: The authors declare no conflict of interest.

Funding: none.

Received for publication: 18 December 2019.

Revision received: 6 March 2020.

Accepted for publication: 30 March 2020.

This work is licensed under a Creative Commons Attribution-NonCommercial 4.0 International License (CC BY-NC 4.0).

(C) Copyright: the Author(s), 2020

Licensee PAGEPress, Italy

Italian Journal of Food Safety 2020; 9:8774 doi:10.4081/ijfs.2020.8774

restoration of a batch of alive $E$. sinensis crabs, conducted in 2018, by the UFS (Functional Simple Unit) veterinary public health and food safety of the ASL Toscana Centro aimed at bringing to the attention criticalities correlated to the introduction of alien invasive species on the National market. Particularly the study focused on both the environmental impact and possible health concerns related to the consumption of an unauthorized and unchecked product.

\section{Materials and Methods}

In December 2018, two following seizures were conducted by the UFS veterinary public health and food safety of the ASL Toscana Centro towards two different ethnic catering establishments within Florence province; two batches of $5 \mathrm{~kg}$ and $10 \mathrm{~kg}$ of live crabs were blocked. The crabs were kept in their original polystyrene packaging and stored at around $0-4^{\circ} \mathrm{C}$ in accordance with their ascertained tolerance to low temperature (DAISIE, 2016;

http://www.fao.org/tempref/FI/DOCUMEN T/aquaculture/CulturedSpecies/file/en/en_ch ineserivercrab.htm) in order to maintain a low specimen metabolism and a low mortality rate during the storage. During the control activity a representative number of specimens included in each of the batches, 
selected according to the size and sex, were photographed and the specific morphological parameters were compared with the reference tables to confirm the species. Furthermore, all the data reported on the commercial documents were recorded. In particular all the data related to commercial and scientific designation, products origin and fishing area, storage conditions and sales destination were registered. At the end of the activities related to the seizure all the animals were subjected to euthanasia in respect of animal welfare.

\section{Results}

\section{Specimens identification}

As regard as the morphological analysis the specimens photographed presented a squared, convex carapace with the typical dark green color tending to gray (Figures 1 and 2). The average carapace width was 5-7 $\mathrm{cm}$, with the presence of the 4 lateral spines on both sides of which the last one being less developed in the cranio-caudal direction (Figure 1). The limbs appeared well developed and almost twice longer than the carapace. In the infraorbital region, a Vshaped notch was present (Figure 1). The abdomen presented a specific sexual related shape with a typical funnel drawing cavity well evident in all the male specimens (Figure 3). Typical claws with sleeves carrying dark brown hair were highlighted in both sexes although less developed in the female specimens (Figures 3 and 4).

The comparison of the characteristics just described with the reference parameters reported in the bibliography (http://www.issg.org/database,

https://www.fws.gov, Veilleux and De Lafontaine 2007) confirmed for all the specimens the belonging to $E$. sinensis species.

\section{Products traceability and labelling}

The analysis of the accompanying documentation was carried out only on the second of the two batches subject to seizure as no traceability elements could be found for the first one.

The second batch was labelled with the commercial designation Hairy crab and the scientific name $E$. sinensis accompanied by the additional notes not intended for human consumption and the product needs to be kept alive until the purchase. Furthermore, the specimens were declared belonging to FAO Area 27.IV sub area C (Ijsselmeer Bay, Holland).

\section{Discussion}

\section{Specimens identification}

The specimens examined had medium dimensions in line with the commercial sizes reported in bibliography although the possibility of adult subjects reaching a width of $10 \mathrm{~cm}$ is also reported (Czerniejewski, et al., 2003).

The sexual dimorphism highlighted with regard to the dark brown hairs around the claws is in agreement with the reference data reported in bibliography within the species identification cards. In particular, in our study the presence of more developed and longer claws hair observed in male specimens is in agreement with Rudnick et al., 2000 description.

\section{Traceability and health concerns related to the eventual products con- sumption \\ The ASL control activity has highlighted}

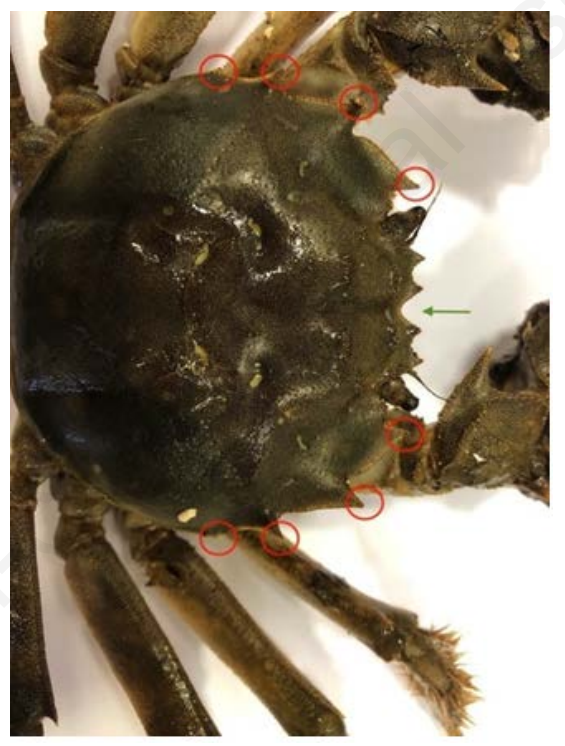

Figure 1. Dorsal view showing the frontal notch and four lateral spines.

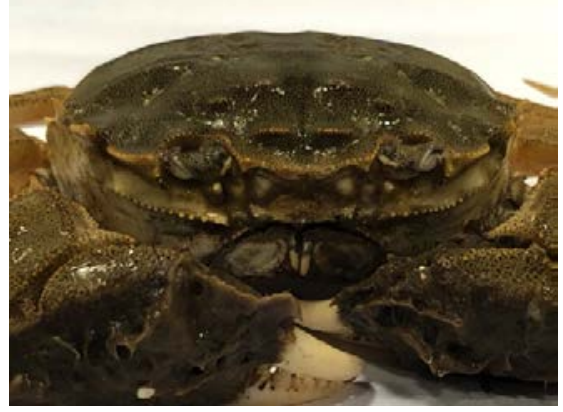

Figure 2. Frontal view of notch. major criticalities in the products traceability management, still persisting especially in the catering sector owned by Asian Food Business Operators (FBO) as previously highlighted in several studies on seafood traceability at ethnic retailers, distributed within Italian borders (D'Amico et al., 2014; Guidi et al., 2010).

The analysis of the data collected pointed out, for one of the two batches, a product corresponding to a FAO area (27.IV, subarea C) previously reported as an open fishing area for E. sinensis (Hoogenboom et al., 2015). In this case, despite the traceability of the product was complete and the fishing area admitted for the species catching, the detention of the alive specimens clearly arose in violation of the current European legislation on the control of alien species (Regulation (EC) $\mathrm{N}^{\circ}$ 1143/2014; Commission Implementing Regulation (EU) 2016/1141).

Furthermore, the wording not intended for human consumption reported on the batch label in question, assumes that the

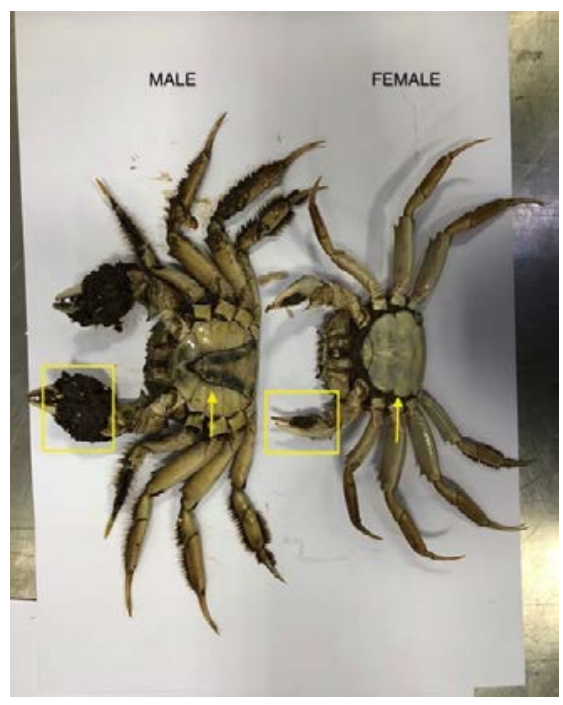

Figure 3. Ventral view of a male (above) and female (below).

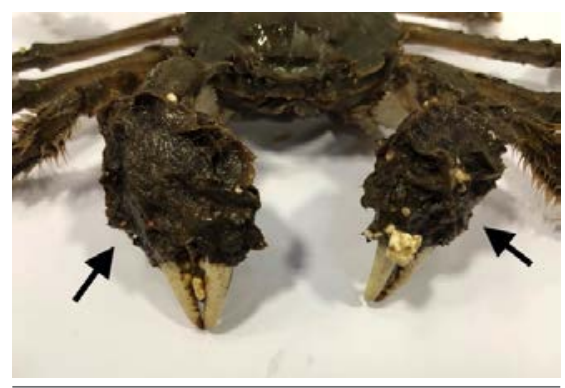

Figure 4. Male Eriocheir sinensis showing hairy claws. 
specimens had not been subjected to the minimum checks for the hygienic-sanitary guarantee of the product with a real risk for the health of the exposed consumers.

In this respect according to current scientific data, E. sinensis is associated to both biological and chemicals hazards. With regard to biological hazards, several studies confirmed the crab as intermediate host of Paragonimus westermani a plathelminthes trematode agent of paragonimiasis (Clark, 2011; Stentiford, 2005; Veldhuizen, 2001). The risk of zoonoses is mainly related to the consumption of raw or undercooked meat containing the metacercarias (Marquardt and Demaree, 1985), which represents the infective stage. However, for the crab infection the presence on the territory of gasteropods belonging to the Thiaridae family that act as first intermediate host is necessary

(https://www.cdc.gov/dpdx/paragonimiasis/i ndex.html). Therefore, given the absence of such gastropods on the European territory (Bentley, 2011), the risk of contracting the parasitosis by consuming specimens fished in the area identified for one of the batches is negligible, however it is no ensured for the other one. About chemical hazards $E$. sinensis has been linked to biomagnification and bioaccumulation phenomena along the food chain of organic contaminants and heavy metals such as Mercury, Cadmium, Lead, Arsenic, Dioxins and PCBs (Dittel and Epifanio, 2009; Clark et al., 2009).

In this regard, specific samplings on the appendicles muscular tissue (white meat) and on hepatopancreas and gonads (brown meat) in E. sinensis specimens fished in the Thames and in the Ijsslemeer bay have been conducted to evaluate levels of contamination from dioxins and PCBs (Clark et al., 2009; Hoogenboom 2015). In both studies, concentrations of PCBs and dioxins well above the Tolerable Daily Intake (TDI) established by European Food Safety Authority (EFSA) and Scientific Advisory Committee on Nutrition (SACN) were confirmed for specimens of Dutch origin

(https://efsa.onlinelibrary.wiley.com/doi/epd f/10.2903/j.efsa.2018.5333; SACN, 2004). This considered, assuming that the batches subjected to seizure had not undergone adequate controls, the chemical risk associated with their consumption cannot be excluded. Furthermore, from the studies of Clark et al., 2009 and Hoogenboom et al.2015 the highest concentration of both contaminants is detectable in gonads and hepatopancreas.

Following these studies, the European Commission issued a recommendation on 3 December 2013 (Recommendation EU No.
2013/711) on the reduction of the presence of dioxins, furans and PCBs in feed and foodstuffs in which, in considerandum 6 , it is suggested to subject E. sinensis to reinforced monitoring as far as it concerns the residues of dioxins, dioxin-like PCBs and PCBs, but above all, in Article 2 it is specified that the monitoring should be carried out on the muscle of the appendices (separately); on brown meat (separately); on the total product (using a calculation that takes into account the levels detected in the appendix and brown meat muscle and their relative proportion). The Recommendation therefore emphasizes the importance of organic contamination in this species and that, referring to the reported studies, contaminant levels should also be detected in brown meats.

Considering that, in relation to Asian culinary traditions, these portions take on greater value than white meat, the associated risk factor is further increased, especially for the most sensitive population categories such as pregnant women and children.

\section{Conclusions}

The study highlighted persistent gaps in the application of traceability measures by some FBOs, particularly within ethnic catering sector, which favored the entry of a highly invasive alien species within the Italian territory where the sightings are still sporadic and limited to some catching areas. Through two sequentially implemented seizures and the identification of the geographical origin of the products, a probable chemical risk emerged that could be correlated to the presence of environmental contaminants of anthropic origin (dioxins and PCBs) inside the products subjected to detention.

A future investigation could be oriented to the identification of the commercial channels that allowed the entry of such products within the Italian territory.

Finally, in a long-term perspective, the study clearly revealed the need to promote active information and training with Asian food business operators in order to improve their awareness of the matter, of food traceability, responsibility and compliance to the European legislation to consumers and environment protection.

\section{References}

Bentley M, 2011. The Global spread of the Chinese Mitten Crab, Eriocheir sinensis, Part II. In Galil B.S, Clark P.F., Carlton
J.T. In the wrong place- Alien marine crustaceans: distribuition Biology and impacts. Springer Netherlands, pp.10727.

Bettison N, Comisso G, 2015. First record of the Chinese mitten crab (Eriocheir sinensis) in the Lagoon of Marano and Grado (Northern Adriatic Sea). Annales Series Historia Naturalis 25:29-34).

Clark PF, 2011. The Commercial exploitation of the Chinese Mitten Crab Eriocheir sinensis in the river Tames, London: Damned if we don't and damned if we do. Part II. In Galil B.S, Clark P.F., Carlton J.T. In the wrong place- Alien marine crustaceans: distribuition Biology and impacts. SpringerScience+Business media B.V 2011.

Clark PF, 2011. The Commercial exploitation of the Chinese Mitten Crab Eriocheir sinensis in the river Tames, London: Damned if we don't and damned if we do. Part II in Galil B.S, Clark P.F., Carlton J.T. In the wrong place- Alien marine crustaceans: distribution Biology and impacts. Springer Netherlands, pp. 537-80.

Clark PF, Mortimer DN, Law RJ, Averns JM, Cohen BA, Wood D, Rose MD, Fernandes AR, Rainbow PS, 2009. Dioxin and PCB contamination in Chinese mitten crabs: human consumption as a control mechanism for an invasive species. Environ Sci Technol 43:1624-9.

Commission Implementing Regulation (Eu) 2016/1141 of 13 July 2016 adopting a list of invasive alien species of Union concern pursuant to Regulation (EU) No 1143/2014 of the European Parliament and of the Council. Available from: https:/eur-lex.europa.eu/legalcontent/EN/TXT/PDF/?uri=CELEX:32 016R1141\& from $=$ IT

Commission Recommendation of 3 december 2013 on the reduction of the presence of dioxins, furans and PCBs in feed and food, (2013/711/EU). Available online: https://eur-lex.europa.eu/legalcontent/en/txt/html/?uri=celex:32013h0 711\&from $=$ it

Council regulation (EC) 1143/2014 Of the European Parliament and Of The Council of 22 October 2014 on the prevention and management of the introduction and spread of invasive alien species. Available from: https://eurlex.europa.eu/legal-cotent/EN/TXT/PD F/?uri=CELEX:32014R1143\& from $=$ IT

Czerniejewski P, Filipiak J, Radziejewska T, 2003. Body weight and morphometry of the chinese mitten crab (Eriocheir sinensis H. Milne-Edwards, 1983) in the 
river Odra/Oder estuary (North-Western Poland). Acta Scientiarum Polonorum. Piscaria (Poland).

D’Amico P, Armani A, Castigliego L, Sheng G, Gianfaldoni D, Guidi A, 2014. Seafood tracea-bility issues in Chinese food business activities in the light of the European provisions. Food Control 35:7-13.

DAISIE, 2015. Delivering Alien Invasive Species Inventories for Europe: 100 of the worst. http://www. europealiens.org/speciesTheWorst.do. Accessed: June $22^{\text {nd }}, 2015$.

Dittel AI, Epifanio CE, 2009. Invasion biology of the Chinese mitten crab Eriochier sinensis: A brief review. J Exper Marine Biol Ecol, 374:79-92.

Fernandes A, Gallani B, Gem M, White S, Rose M, 2004. Trends in the dioxin and PCB content of the UK diet. Organohalogen compounds 66:2053-60.

Fiorin R, Riccato F, Colla S, Franzoi P, CostantiniU, 2013. Eriocheir sinensis (H. Milne Edwars, 1853): seconda segnalazione per la Laguna di Venezia. Boll Mus Stor Nat Venezia, 2013.

Guidi A, Armani A, Castigliego L, Li XN, Fanzone F, Fusco S, Facibeni E, Gianfaldoni D, 2010. Labeling of ethnic food in the Prato Chinese community. Vet Res Commun 34:163-6.

Hoogenboom RL, Kotterman MJ, Hoek-van Nieuwenhuizen M, van der Lee MK, Mennes WC, Jeurissen SM, van Leeuwen SP, 2015. Dioxins, PCBs and heavy metals in Chinese mitten crabs from Dutch rivers and lakes. Chemosphere 123:1-8.

Hopkins CCE, 2001. A review of introductions and transfers of alien marine species in the North Sea area. Aqua Marine Advisers http://www.naturforvaltning.no/archive/ attachments/01/04/CHMDA071.pdf.

Hymanson Z, Wang J, Sasaki T, 1999. Lessons from the home of the Chinese mitten crab. IEP Newsletter 12:25-32.

Marquardt WC, Demaree RS, 1985. Parasitology. New York: MacMillan Publishing; pp. 274.

USFWS (United States Fish and Wildlife Service). 1989. Importation or shipment of injurious wildlife: mitten crabs. Federal Register.

Mizzan L, 2005. Rhithropanopeus harrisii (Gould,1841) (Crustacea, Decapoda, Panopeidae) ed Eriocheir sinensis $\mathrm{H}$. Milne Edwards, 1853 (Crustacea, Decapoda, Grapsidae): due nuovi granchi esotici in Laguna di Venezia. Boll Mus Stor Nat Venezia, 2005.

Peng WH, 1986. Preliminary study on the problem of variation of Eriocheir sinensis in Zhujiang river valley. Inf Fish Sci Tech 2:19-22.

Petit G, 1960. Le crabe chinois est parvenu en Méditerranée. Vie et Milieu 11:1336.

Rainbow P, Robbins R, Clark P, 2003. Alien invaders: Chinese mitten crabs in the Thames and spreading. Biologist 50:5.

Rudnick DA, Halat KM, Resh VH, 2000. Distribution, ecology and potential impacts of the Chinese mitten crab (Eriocheir sinensis) in San Francisco Bay. Available from: http://www.aquaticnuisance.org/wordpre ss/wp-

content/uploads/2009/01/Chinese $\% 20 \mathrm{M}$ itten $\% 20 \mathrm{Crab} \% 20 \mathrm{in} \% 20 \mathrm{San} \% 20$ Francis co\%20Bay.pdf

Scientific Advisory Committee on Nutrition and Committee on Toxicity (SACN). Advice on Fish Consumption: Benefits and Risks, Section 3; The Stationery Office: London, 2004; ISBN 011 243083. Available from: https:/cot.food.gov.uk/sites/default/files /cot/fishreport200401.pdf

Stentiford GD, 2005. Survey of Chinese mitten crab (Eriocheir sinensis) from the Thames estuary to investigate their potential as vectors for the metacercarial stage of the human lung fluke (Paragonimus westermani). Report by the Centre for Environment, Fisheries and Aquaculture Science (CEFAS) for London Port Health Authority (LPHA), Corporation of London.

Veilleux É, De Lafontaine Y, 2007. Biological synopsis of the Chinese mitten crab (Eriocheir sinensis). Fisheries and Oceans Canada, Science Branch, Pacific Region, Pacific Biological Station.

Veldhuizen T, 2001. Life history, distribution, and impacts of the Chinese mitten crab, Eriocheir sinensis. Aquatic invaders 12:1-9. 